\title{
Sharia in the Nigerian Constitutions: Examining the Constitutional Conferences and the Sharia Debates in the Drafts
}

\author{
Abdulmajeed Hassan-Bello \\ University of Uyo Nigeria, Uyo, Akwa Ibom State, Nigeria \\ e-mail: boladebello@yahoo.com
}

\begin{abstract}
The paper examines the socio-ethnic and religious configuration of Nigeria and the nature of Sharia debates in the Nigeria constitutions of 1977/1978; 1988/1989 debates and Constitutional Conference of 1994/1995. The paper argues that the genesis of the Sharia debates can be traced to 1956. The Constitutional Conference of 1994/95 was not bedeviled by a serious acrimonious debate over the Sharia. However, the 1999 constitution brought a new dimension to the issue of the Sharia. To some extent, the enactment of Sharia law in Nigeria is a prime example of the relative success of Nigeria's multi-state federalism in regards to governing diversity. Particularly the political autonomy to establish a Sharia Court of Appeal with civil jurisdiction on Islamic personal law. The paper concludes that the constitutionalization of the Sharia has subjected it to the vagaries of the political wind and made it easy prey to political fortune-seekers. Thus, the matters relating to religions should be removed from the future deliberative process in the country.

\section{[1}

Artikel ini meneliti konfigurasi sosial-etnis dan agama Nigeria dan sifat perdebatan syariah dalam konstitusi Nigeria 1977/1978; 1988/1989 debat dan Konferensi Konstitusi 1994/1995. Artikel ini berpendapat bahwa asal-usul perdebatan syariah dapat ditelusuri ke tahun 1956. Konferensi Konstitusi 1994/95 tidak diliputi oleh perdebatan sengit yang serius tentang syariah. Namun, konstitusi 1999 membawa dimensi baru pada masalah Syariah. Hingga taraf tertentu, pemberlakuan hukum syariah di Nigeria adalah contoh utama keberhasilan relatif federalisme multi-negara Nigeria dalam hal mengatur keragaman. Khususnya otonomi politik untuk membentuk Pengadilan Banding Syariah dengan yurisdiksi sipil tentang hukum pribadi Islam. Artikel ini menyimpulkan bahwa konstitusionalisasi syariah telah menjadikannya sebagai angin ribut dari angin politik dan membuatnya menjadi mangsa yang mudah bagi pencari keberuntungan politik. Dengan demikian, hal-hal yang berkaitan dengan agama harus dihapus dari proses musyawarah di masa depan di negara ini.
\end{abstract}

Keywords: absolute-justice; constitution; democracy; equality; hudūd; Sharia court 
Abdulmajeed Hassan-Bello

\section{Introduction}

Muslims of Nigeria, particularly in the North, were totally governed by Islamic Law in the past. The advent of colonial rule saw a gradual phasing out of the Islamic Criminal law, Commercial law, Evidence and so on. What was left in the last came to be known as Moslem Personal law. ${ }^{1}$ In addition to this, it is established that Islam and Sharia entered Yoruba land through the North via Bornu, Songhai, Mali, Kano and Nupe in Hausa land. Although the exact date of their entry is not known, there had been evidence of Islamic presence in Yoruba land in $17^{\text {th }}$ century. ${ }^{2}$ This claim is supported by the Yoruba saying -Ile la baifa, Ile la baimole, osan gangan nitiigbagbo, meaning: we met customary law at home as well as Islam while Christianity came later in the day. ${ }^{3}$ Therefore, it is correct to say that before the advent of the colonialists, Islam and its legal system in its full ramification had been with the Muslims in Nigeria for more than a thousand years. The application of Sharia fully blossomed in the areas that constitute the Northern States now and in some notable cities in the Western part of Nigeria like Epe, Iwo and Ede, shortly after the Sokoto Jihad of the 19th Century. ${ }^{4}$ The ability of any political system to survive depends first and foremost on two primary factors: its provision for the basic spiritual and biological needs of man and its allowance for change. It is the contention of this article that Islam meets these two conditions. Aside from spiritual and moral aspects of the creed which are permanently established, Islam provides broad principles and frameworks in the area of worldly interactions which makes it possible for the Muslim community to evolve and meet the needs of every period. ${ }^{5}$

A constitution is a system of devices through which political power is divided within a community. It is clearly distinct from absolutism, which

${ }^{1}$ Syed Khalid Rashid, "Introduction," in Islamic Law in Nigeria (Application \& Teaching), ed. Syed Khalid Rashid (Lagos: Islamic Publications Bureau, 1986), 1-7.

2G. O. Gbadamasi, "The Growth of Islam Among the Yorubas (1841-1908)" (Ph.D. Thesis, University of Ibadan, 1968), 64.

3Muri Okunola, "The Relevance of Sharia to Nigeria," in Islamic Law in Nigeria (Application \& Teaching), ed. Syed Khalid Rashid (Lagos: Islamic Publications Bureau, 1986), 23-25.

4Yusuf Ali, "The Legal Status and Politics of Shariah in Nigeria," Yusuf Ali \& Co., n.d, https://yusufali.net/articles/The_Legal_Status_and_Politics_of_Shariah_in_Nigeria.pdf.

${ }^{5}$ Lukman Thaib, "Concept of Political Authority in the Islamic Political Thought," International Journal of Humanities and Social Science Invention 1, no. 1 (2012): 12-19, www.ijhssi.org. 
signifies a concentration of political power. It is also distinct from anarchy, which seeks not merely to limit political power but to destroy it. ${ }^{6}$ Religious beliefs have through the ages been the main anchor of morality, providing the necessary sanction and helping to transmit it from generation to generation. Such has been the linkage of the one with the other that it is said morality cannot exist without religion. ${ }^{7}$

Given the indispensable role of religion in fostering happiness, discipline, harmony, stability, liberty and democracy, it is tempting to say that the state should positively support and promote religion, so long as it does so on the footing of the equality of all religions, and that it should not by standing aloof completely in all matters of religion, lend encouragement to irreligion among its subjects. Liberty and democracy took root and flourished in the United States because, the people were virtuous; they are virtuous because they were moral; they were moral because they were religious. ${ }^{8}$

The British colonial rule in Nigeria which spanned 1861 - 1960 and the legacy of that colonialists sowed the seed of crises, domestic contradictions and general conflicts in all ramifications. In this vein, the exploitation of the existing ethnic and other identity based groups, as indeed the apparent differences of Islam and Christianity, the two dominant religions, and the apparent religious democracy in the country, have become contentious issues posing serious challenges to the political, and corporate existence of Nigeria in the 21st century. Thus, Islam as a civilization and worldview predates modern Nigeria. It was established as a state religion in a larger environment that comprised almost all the parts of Northern Nigeria and beyond. As such therefore, Islamic law technically called the Sharia served all sectors, functionalities and structures before the British occupation. ${ }^{9}$

\footnotetext{
${ }^{6}$ Dell Gillette \& Harbold and William Henry Hitchner, Modern Government: A Survey of Political Science (New York: Dodd, Mead \& Company, 1966), 193.

${ }^{7}$ Ben O. Nwabueze, Ideas and Facts in Constitution Making (Ibadan: Spectrum Books Limited, 1993), 255

${ }^{8}$ Nwabueze.

9Juwayriya Badamasiuy and Ahmed Adam Okene, "Shari'ah Implementation in a Democratic Nigeria: Historical Background and the Quest for Developmental Legality," Journal of Politics and Law 4, no. 2 (2011): 144-52, https://www.academia.edu/890544/Shariah_Implementation_in_ Democratic_Nigeria_Historical_Background_and_The_Quest_for_Developmental_Legality.
} 
The circumstances in which the replacement and reform of the Sharia took place resulted in political tensions between the westernized elites and other, more traditional segments of Muslim societies. The masses remained attached to the idea of the supremacy of Sharia law, anticipating that its reinstatement would cure endemic political, economic, and social ills. The fuqahä' continued to study and defend the Sharia and were offended by their displacement by the new class of lawyers and judges trained in Western law; as traditional guardians of the Sharia heritage, the fuqah $\bar{a}^{\prime}$ also retained prestige and a popular following among the masses. Meanwhile the forces of what has come to be known as political Islam, in which Islam was converted to a populist political ideology, won support from disaffected urban dwellers for their proposals for Islamization..$^{10}$ This paper will examine Socio-ethnic and religious configuration of Nigeria, three draft constitutions that generated hot debate concerning inclusion of religious Sharia. They are 1979 Constitution, 1989 and 1995. This is because the $1994 / 1995$ constitutional debate was not be deviled by serious acrimonious debate over the Sharia, the 1998 Constitutional Debate Co-ordination Committee recommendation for the retention of the provisions of the 1995 draft Constitution became smeared in severe controversy. Ultimately, the post 1995 era civil governance is anchored based on the 1999 constitution. The paper is primarily, sharia study thus, a prime method for collecting information has been the textual analysis of primary sources of sharia, the Qur'an and Sunnah. Academic works of modern Muslim jurists and thinkers and other journals were also extensively consulted.

\section{Socio-ethnic and Religious Configuration of Nigeria}

Ethnicity and religion are two issues that have played dominant roles in the way of life and governance in Africa. Thus, the political behavior of many Nigerians is still influenced heavily by the hyperbolic assumption that one's destiny is intrinsically and exclusively link with one's ethnic, linguistic and religious identity. ${ }^{11}$ In the past, Nigeria was believed to be made up of the

\footnotetext{
10Lindsay Jones, ed., "History of Shariah," Encyclopedia of Religion (USA: Macmillan Reference, 2004).

${ }^{11}$ Otive Igbuzor, "Nigeria's Experience in Managing the Challenges of Ethnic and Religious Diversity through Constitutional Provisions," n.d., http://www.idea.int/asia_pacific/myanmar/ upload/burma_report, accessed 19 September, 2018.
} 
Hausas in the north, the Igbos in the east and the Yorubas in the west, although further studies have rendered the classification a fallacy and an oversimplification. The north and east have paid dearly for this popular but incorrect assumption. The large number of minority ethnic groups in the north have relentlessly challenged their domination by the Hausas, while diverse ethnic groups in the east and part of the west ensured the creation of the midwest region shortly after the dawn of independence. It can also, arguably, be said that one of the underlying motivations for the birth of the defunct Republic of Biafra was the control of the minority groups in what was then known as Eastern Nigeria. ${ }^{12}$

Before the advent of the British, there were hundreds of distinct ethnic and linguistic groups in the vast area now known as Nigeria. Each group, particularly in the south, had its own unique culture and system of governance. The Northern part of what is now referred to as Nigeria was more politically and administratively centralised than the independent kingdoms and autonomous communities in the south. The definition of either north or south is also contentious since some northerners, such as the Yorubas of the north, only grudgingly accept being tagged northerners. ${ }^{13}$

The north, though made up of many ethnic groups, has Hausa as its lingua franca, since almost all the groups (with the exception of the Yorubas) have adopted it as the official medium of communication. The north was also unified and administered by an Islamic movement led by Usmanu Dan Fodiyo in 1804. The official religion in the north was indisputably Islam, though other religions were allowed and tolerated. Arabic was said to be the official language, but this was also a fallacy. The official language was Hausa, though the leadership of the movement was Fulani, a Fulfude-speaking ethnic group. Arabic script was used to transcribe the Hausa language. For example, up until the early part of this century, any Nigerian currency had a Hausa transcription of its value, but was written in Arabic script. The deletion of this feature from the currency during

\footnotetext{
${ }^{12}$ Is-haq Olanrewaju Oloyede, "Theologising the Mundane, Politicising the Divine: The CrossCurrents of Law, Religion and Ppolitics in Nigeria," African Human Right Law Journal 14, no. 1 (2014): 178-202, http://www.ahrlj.up.ac.za/issues/2014/volume-14-no-1-2014/41-issues/volume-14-no1-2014/435-theologising-the-mundane-politicising-the-divine-the-cross-currents-of-law-religionand-politics-in-nigeria.

${ }^{13}$ Oloyede, 180.
} 
the civilian regime of President Olusegun Obasanjo (1999-2007), based on the incorrect premise that it was Arabic or Islamic, is an instance of theologising the mundane. ${ }^{14}$

In the Nigeria political structure, the north was essentially feudalistic. The east was essentially republican with autonomous communities, while the west was also feudalistic but with some modern refinement due to the influence of Western civilisation. The British colonialists adopted direct rule in Lagos and the southern protectorate, while the Northern protectorate had indirect rule through the established kings (emirs) who wielded both religious and political power, in what was essential Islamic rule. The rulers in South Western Nigeria also held both political and religious power. The religious power of the southern kings, however, concerned traditional religious rites which did not in the main cover either Islam or Christianity. With political authorities exerting control on religions, the politicisation of the divine became a natural corollary. Christians and adherents of African traditional religion in the north were essentially regarded as second-class citizens, much as Muslims were regarded in the south. The British encouraged the Christianisation of the south while being cautious in the dissemination of Christianity in the north. The protests of the Muslims in the south were largely ignored. ${ }^{15}$

There are three major sources of law in Nigeria. They are Euro-Christian British law, referred to as common law, Islamic law and customary law.16 The law traditionally applicable in Nigeria was customary law. In the north, before the advent of British rule, the applicable law in most of Northern Nigeria was Islamic law, which was regarded as customary law. ${ }^{17}$ The British introduced common law, with some modifications, to accommodate prevalent Islamic law in the north. In the south, the British common law, with a large dose of Christian ethics and practice, was made to co-exist with or even subvert customary law.

${ }^{14}$ Oloyede.

15J. N. D. Anderson, Islamic Law in Africa (London: Frank Cass, 1955), 222-3.

${ }^{16}$ A. G. Karibi-Whyte, History and Sources of Nigerian Criminal Law (Ibadan: Spectrum Books Limited, 1993), 58.

17Jamil M. Abun-Nasr, "The Recognition of Islamic Law in Nigeria as Customary Law," in Law, Society, and National Identity in Africa, ed. Jamil M. Abun-Nasr, Ulrich Spellenberg, and Ulrike Wanitzek (Hamburg: H. Buske, 1990), 31-44. 
With the amalgamation of the Northern and Southern protectorates of Nigeria in 1914, the British classified Islamic law as the customary law of Northern Nigeria. The implication of that was not immediately obvious to the peoples of Northern Nigeria. The subsequent invocation of the repugnancy doctrine to nullify some Islamic court judgments attracted some protests from the north. Muslims in the south, especially in the south west where they are in the majority, looked to Northern Muslims for religious relief, which was not as forthcoming as expected. This explains, to a large extent, the uneasy relationship between the two Muslim groups in Nigeria up to the present day. ${ }^{18}$

In many federal systems around the world, the constituent units are blocks which come together to submit their overall sovereignty to a central authority, while retaining control over certain specific features of government. In the case of Nigeria, the constituent units are not only the creation of the central authority, but each is also as internally heterogeneous as the overall federation. The composition of many of the constituent units is not based on any historical, cultural or linguistic affinity. They are merely a proclamation of the central authorities. Consequently, the agitation for more states is still as intense as ever. ${ }^{19}$

The north, generally speaking, had been under a central Islamic government in the early part of the nineteenth century. The British created what is known as Southern Nigeria from a large number of diverse ethnic groups. The British then split the southern areas into the western and eastern regions, based only on geographical proximity. Consequently, at independence, Nigeria had three constituent units - North, West and East. In 1964, the midwest was carved out of the west and some parts of the east. In 1967, the federal military government decreed 12 states out of these regions. The number rose to 19 in 1976; 21 in 1987; 30 in 1995; and 36 in 1997. The 36 states are today regarded as the constituents of the 'federation', which is more unitary than federal. The military later informally introduced a supra-state structure called 'the Six Geo-Political Zones', which again have neither the mandate of the citizens, nor internal coherence or cultural identity. ${ }^{20}$

180loyede, "Theologising the Mundane, Politicising the Divine," 182.

190loyede.

200loyede, 182-3. 


\section{Nigeria Constitution Draft Committee and Sharia Debates}

\section{Sharia Debate 1977-1978}

Sharia debates go back a long way. Southerners and the northern Christians in Nigeria believe that the Sharia debate at the Constituent Assembly (CA) in 1977/1978 is part of the history of Sharia of Nigeria that it was the General Murtala Muhammad's plan for the Islamization of Nigeria, which formed the basis of the Sharia provision in the Draft Constitution. However, the determination of the members of Constituent Assembly from the Middle-belt working with the members from the Southern minorities of then Bendel, Rivers and Cross River States that successfully put a check on the planned Islamization of Nigeria after the death of General Murtala. ${ }^{21}$ Paul Unongo from Benue who opposed the Sharia in the CDC could not stop the inclusion of the Sharia provision in the Draft Constitution. Having failed at the CDC, he sought election to the Constituent Assembly from Benue along with others from the Middle-Belt on the anti-Sharia platform. The Middle-Belt members and the members from the southern minorities in the Constituent Assembly were able to build a consensus on the Sharia, the Revenue Allocation and the Presidential System. ${ }^{22}$

The crisis over Sharia in the Constituent Assembly was resolved in the Constituent Assembly. But because the Constituent Assembly was not sovereign, that that it did not have a final say on the decision on Sharia. Its decision was subject to the overriding approval of the Supreme Military Council; hence the Sharia provision in the final Constitution was fundamentally amended by the Supreme Military Council under the chairmanship of General Olusegun Obasanjo. Obasanjo, as the successor of General Murtala had problems with pushing through, the Islamization Plan of Murtala. The believers in Murtala's Islamization Plan in the Supreme Military Council, Shehu Yar'Adua, Babangida and Buhari were not powerful enough to push the plan through. They had problems with the avid defenders of the secularism in the

\footnotetext{
${ }^{21}$ Omo Omoruyi, "An Appeal to President Olusegun Obasanjo: Nigeria: Neither an Islamic nor a Christian Country," Nigeriaworld, 2001, accessed 28 August 2016 https://nigeriaworld.com/ feature/publication/omoruyi/0307001.html.

${ }^{22}$ Omoruyi, 2.
} 
Supreme Military Council led by the Service Chiefs General T. Y Danjunma, Commodore Isa Doko and Rear Admiral Adelanwa. ${ }^{23}$

General Obasanjo did not see anything wrong with the provision as propounded by the Pro- Sharia zealots. He did not see anything wrong with having the Sharia Court up to the highest level of the federal judiciary with a Grand Mufti as the head of the Federal Supreme Sharia Court. He was not opposed to the plan to have parity between the Chief Justice of the Supreme Court and the Grand Mufti of the Supreme Sharia Court. Under the provision in the Draft Constitution, the Grand Mufti was to have the same power like the Chief Justice of the Federation to swear in the President, Commander in Chief. Of course, the protagonists of the plan knew that the President would always be a Muslim. It was obvious then that the successor regime to the military whether civilian or military would whittle down the gains made in the Constituent Assembly. Alhaji Shagari became the President in 1979 but, the dynamics of the civilian politics did not make it possible for the new civilian to push for a full scale Islamization of the country between 1979 and $1983 .{ }^{24}$

The genesis of the Sharia debate of 1977-1978 can be traced to 1956. In 1956, a regional law was passed to establish the Muslim court of appeal. The main function of this court was to hear appeal from the decision of native courts on suits pertaining to the personal status of Muslims such as marriage, divorce, custody of children, inheritance, etc.25 The 1963 regional constitutions of the north subsequently recognized and duly retained this court for the region with a slight change in its application. It was redesigned as the Sharia Court of appeal. Thus, the Sharia debate during the 1977/1978 constitution draft is not General Muritala agenda to Islamize Nigeria. The period between 1977/1978 may be the starting point of the constitution debate. The then military administration had, in 1976, promised to relinquish power to democratically elected civilian regime. Preparatory to this, a draft constitution had been drawn up and submitted to an intense and pervasive public debate for a year. ${ }^{26}$

\footnotetext{
${ }^{23}$ Omoruyi, 3.

${ }^{24}$ Omoruyi, 5 .

${ }^{25}$ Auwalu Hamisu Yadudu, “The Prospect for Shari'a in Nigeria," in Islam in Nigeria, ed. Nura Alkali (Ibadan: Spectrum Books Limited, 1993), 47.

${ }^{26}$ Yadudu, 48.
} 
It is however observed that one serious mistake made by the constitution Drafting Committee (CDC) was to design a single constitutional document for the entire federation. In addition, many Nigerians have come to ignore the diversity of the country which the constitution reflected and behave as if the single document had suddenly dispensed with the religious, geographical and cultural diversities and imposed in their place some uniform standards. ${ }^{27}$

The debate on the draft constitution of 1976 has clearly revealed the confusion and fallacies it has helped to generate. Nigerians, from the Southern part of the country, who were unaware that the north has had the Sharia court of appeal now, faced with a single federal constitution, vowed to remove the Sharia provision from the document even though the draft constitution did not seek to extend the jurisdiction of the court to them. The draft only provided that any state which required it may establish a Sharia Court of appeal. There was an additional proposal for the establishment of a federal Sharia court of appeal. This time around, there was opposition to both proposal from the southerners generally, and northern Christians in particular. ${ }^{28}$ While the fact is that Nigeria was a federation and therefore there must be diversities. We must recognize various and different jurisdictions. But non-Muslim should not be subjected to the jurisdiction of Sharia.

As the debate continued in the press, on the floor of the constituent assembly, the matter become clear that the simple issue of a court was turned into a pawn in the political game of party formation and political alliances. The debate impeded a smooth deliberation process in the assembly and led to stalemate which was resolved by the military. The simple solution offered by the military was to retain the provision which enable any state which requires it to establish the Sharia court of Appeal into the then Federal Court of Appeal by creating: Sharia division within it. That ended the matter for the 1977-1978 round of the Sharia debate..$^{29}$

In the discussing the position accorded to the Sharia in the 1979 constitution, two observations have to be made first, because they srtikeat very

\footnotetext{
${ }^{27}$ Yadudu.

${ }^{28}$ Yadudu.

${ }^{29}$ Yadudu.
} 
root of the matter. The first is that, Islam, to a considerable number of the members of the Constitution Drafting Committee, (C.D.C) and the constituent Assembly (C.A) was not a way of life, but a religion among religions; and religion, to some of them, is a thing of the past. This erroneous conception about Islam is derived from the anti-Islamic education which they have received from the colonialists and imperialists. The second observation is that the (C.D.C) deliberately refused to avail itself of the Constitutional principles of Islam as enunciated by the leaders and scholars of Islamic states which had existed in Nigeria i.e. Borno and Sokoto. Instead the (C.D.C) focused its attention on Europe and America. To what extent then, is the constitution based on any Nigerian history and experience as a people. ${ }^{30}$ Therefore, whenever there is a discussion on the Nigeria future the attention were all about whether to return to what British bequeathed or to search for other alternative from somewhere else, but not from any Islamic law which is the law of northern part of the country before the colonization.

\section{The 1988-1989 Debate}

A decade later, Nigerians were called upon to deliberate over another constitutional document, preparatory to handing over power to civilians in 1992; the incumbent military regime had once again appointed a body, the Constitution Review Committee (CRC), to review the 1979 federal constitution. The CRC has made some qualitative improvement to this document and produced a draft which was table before a Constituent Assembly (CA). As far as provisions on the Sharia Court of Appeal were concerned, the CRC draft virtually retained the feature of the 1979 constitution. ${ }^{31}$

Under clauses 254 to 258 , any state which requires the court may establish it. Only Muslims are subject to the court's jurisdiction. As with previous provisions, non-Muslims who desire may submit to its jurisdiction by voluntarily exercising the option in writing. The CRC did not even revisit the issue of the establishment of the Federal Sharia court of Appeal. The CRC also incorporated some amendments which the military had made to clarify the

\footnotetext{
30Ibrahim R. Sulaiman, "The Shari'ah and the Constitution," in Islamic Law in Nigeria (Application \& Teaching), ed. Syed Khalid Rashid (Lagos: Islamic Publications Bureau, 1986), 52-74.

${ }^{31}$ Yadudu, "The Prospect for Shari'a in Nigeria," 49.
} 
jurisdiction of the Sharia Court of Appeal in respect of civil matters other than those pertaining to the personal status of Muslims. One would have thought that if anything was going to occupy the attention of the CA, it would not be the provisions on the Sharia. It was not to be so. Some interest groups had been spoiling for a fight with Muslims. The unfinished business of 1978 was carried forward and attended to with more ferocity and reckless abandon. Many factors had combined to instigate those bent on taking up issues with Muslims to avail themselves of the opportunity offered by the constitutional debates on the floor of the Constituent Assembly. As it turned out, the Sharia was the guinea pig on which to experiment a number of things with a view to testing the mettle of Muslims. ${ }^{32}$

As with the 1978 constituent assembly proceedings, political alliances had to be formed. Especially in two states in the North, Gongola ${ }^{33}$ and Kaduna religious politics had been played out during the 1987 local government elections which, subsequently, affected the outcome of the 1988 indirect elections of members who would represent these states in the constituent assembly. Members from these states and a few other constituencies had been elected on anti-Sharia from the draft constitution. There were also catalogues of demands and shopping list of items of concessions to be wrested from the hands of the muslins by hurriedly formed religious caucus. These were demands that had no constitutional relevance or over which the CA had no mandate to deliberate upon. Nevertheless, the opportunity had offered itself and it was seized. It must be mentioned too that the activities of these antiSharia coalitions were carefully planned, monitored and directed by the Christian Association of Nigeria, (CAN). CAN had also carried out an orchestrated propaganda to whip up religious emotions of its followers against anything in the draft constitutions which had any Islamic semblance to it. It had sponsored the publication of propaganda materials and was, throughout the sitting of the CA, holding one press conference after another to instigate its supporters and spread bad blood in the CA. ${ }^{34}$

\footnotetext{
${ }^{32}$ Yadudu.

${ }^{33}$ Gongola state is a former administrative division of Nigeria. It was created on $3^{\text {rd }}$ February 1976 from Adamawa and Sardauna Provinces of North State; it existed until August 1991, when it was divided into two States- Adamawa and Taraba. "Gongola State of Nigeria Executive Council," en.wikipedia.org, n.d., https://en.wikipedia.org/wiki/Gongola_State.

${ }^{34}$ Yadudu, "The Prospect for Shari'a in Nigeria," 50.
} 
CAN even threatened the Armed Forces Ruling Council (AFRC) that if they decided to rubber-stamp the desires of Muslims supposedly by approving a constitution in which there is some mention of the Sharia they shall reject that constitution and the AFRC must be ready to produce for the Christians in the country a Christian constitution that recognizes ecclesiastical courts. This would have been the best. Strangely, when some Muslim members of the CA filed a motion on the floor of the CA supporting the entrenchment of the said ecclesiastical courts, not one Christian applauded the idea or supported it, the CAN, did not considered it worthwhile to move a similar motion on their own part. ${ }^{35}$

By the time the CA convened to proceed with the deliberation on the draft constitution produced by the CDC, a game-plan for the second round of the Sharia debate had been worked out by the northern Christians and their allies. The onslaught was three-pronged and designed to achieve several objectives. They had vowed to ensure that there would not be any mention of Sharia in the constitution. On failing to achieve this objective, intense pressure was to be brought to bear on the Muslims with a view to squeezing some political concessions out of them. Thirdly, the Muslims were to be engaged with frivolous discussion with a view to diverting their attention from pursuing any positive goal of their own. Briefly, we explain how and what efforts were made to achieve these broad goals all under the pretext of engaging in constitutional deliberation and participation in the Sharia debate. ${ }^{36}$

To ensure that all clauses in the draft constitution on the Sharia Court of Appeal are expunged completely, election to the $\mathrm{CA}$ in the two state mentioned above was manipulated so as to send an all-Christian delegation for effective participation in the numbers-game called democracy. In furtherance of this objective, the leadership of the CA skewed the membership of key committees which deliberated at the committee stage on provisions relating to the Sharia Court of Appeal. Committee No. 16, which handled State Judicature, was flooded with an absolute majority of Christians. As if that was not enough, it had the complement of three Reverend gentlemen on it. Committee No. 3

${ }^{35}$ Yadudu, 50.

${ }^{36}$ Yadudu. 
among other things, deliberated on the clauses relating to the judicial powers of the Federation, was similarly packed with a majority of Christian members. ${ }^{37}$ When confronted with these starting revelations about the composition of crucial committees, the chairman of the Assembly pleaded ignorance of the religious affiliation of members and claimed that he had paid no attention whatsoever to this in his placement of members to committee! He said:

There never was anything like singing out an issue of religion to determine the membership of those committees. It is very clear. I would, therefore appeal to you not to succumb to agencies of destruction I would appeal to you to take into account the interest of this nation..$^{38}$

Consequently, he added a few Muslims but refused to remedy the imbalance in the membership of the committees. Indeed, at some point during the stalemate reached over the issue of the Sharia Court of Appeal and the High Court of Justice, the CA chairman, fully aware of the unrepresentative nature of committee No. 3, instructed its chairman to carry out a vote to determine who were in support or against deleting a key clause which pertained to the Sharia. This was, of course, contrary to the very guidelines he had earlier issued to all committees proscribing voting and urging members to strive to arrive at decisions by consensus. Guidelines and Programs of Work stipulated "It is desirable that decisions of the committee of the whole House be arrived at by consensus". ${ }^{39}$ To many members of the CA, the chairman's attitude was not at all surprising. It was all part of a carefully designed game-plan. This did not succeed, also. ${ }^{40}$

After the House had adjourned the next sitting to Monday, 28 November, 1988, from Tuesday, 22 November, 1988, the Chairman Constituent Assembly travelled to Lagos and explained to Mr. President and to the Chief of General Staff, vice Admiral Augustus Aikhomu, what have been happening in the Constituent Assembly and made it clear to them that the Assembly would not be able to arrive at a consensus on the Sharia question, and therefore, it was

\footnotetext{
37Yadudu, 51.

${ }^{38}$ Anthony Nnaemezie Aniagolu, The Making of the 1989 Constitution of Nigeria (Ibadan: Spectrum Books Limited, 1993), 114.

${ }^{39}$ Aniagolu, 137.

${ }^{40}$ Yadudu, "The Prospect for Shari'a in Nigeria," 51.
} 
necessary for government to decide on its own line of action. The Chief of General Staff, Vice-Admiral Augustus Aikhomu, chided those opposed to Sharia who could not appreciate the consensus which the Nigerian public has formed over the matter. He said that the sacred responsibility of the Constituent Assembly does not involve altering, without just and reasonable cause, fundamental principles and structures of the 1979 Constitution as reviewed by the Constitution Review Committee. Therefore, government decided that it is in the national interest of the Assembly itself, to exclude Clause 6 (2) to 6 (d) and 248 to 263 both inclusive of the reviewed constitution from your jurisdiction. Accordingly, the Federal Military Government has decided that this Assembly should stop further debate and discussion on these clauses. ${ }^{41}$

It is obvious that Sharia debate during the 1988-1989 constitutional deliberations became one in which politicians wanted to invest heavily in and hoped to reap huge gains from. Of course, all this was done with an eye on partisan politics which would be unleashed following the promulgation of the new constitution. Moreover, opinion was sharply divided over which of the symbols of two contending systems of laws were to be blessed with constitutional protection. A stalemate was reached. And just as was the case with the 1977-1978 exercise, the inability of the civilians to come to terms over matters of vital national importance necessitated a military intervention. On the morning of 28 November, 1988 the Federal military government withdrew jurisdiction from the assembly over clauses dealing with the establishment, composition and jurisdiction of the High Court, Sharia and Customary Courts of Appeal of the state. ${ }^{42}$

Indeed, on 28 November, 1988, the order Paper for the day's proceedings of the Assembly contained a motion moved by the spokesmen of the anti- Sharia coalition which called for the removal of certain sub-clauses from the clause 6 of the draft constitution. Incidentally, this is the provision which recognizes the Sharia Court of Appeal as a Superior Court of Record along with the High Court of Justice and several others. There was on the same order paper another motion singed by 15 and supported by 289 other members of the Assembly which called

\footnotetext{
${ }^{41}$ Aniagolu, The Making of the 1989 Constitution of Nigeria, 143-4.

${ }^{42}$ Yadudu, "The Prospect for Sharia in Nigeria," 54.
} 
for the retention of the same clause as proposed by CRC. It is, perhaps, arguable that had the Assembly's jurisdiction not been withdrawn, the anti- Sharia coalition would have, anyway, lost the battle that day. ${ }^{43}$

\section{Constitutional Conference of 1994/1995}

The Constitutional Conference 1994 was established by Section 1 of Decree No. 3 of 1994 which came into force on $30^{\text {th }}$ April 1994. The Decree was amended by the Constitutional Conference (Amendment) Decree No. 4 of 1994 which came into force on the $24^{\text {th }}$ June 1994 . The Conference was inaugurated on 27th June 1994 by General Sani Abacha. In his inaugurating speech, the head of State, referred generally to the unfortunate events of the past which necessitated the convening of the Conference and charged the delegates to channel all political creativity towards implanting enduring institutional arrangements that can ensure consolidation and growth of a democratic nation state. ${ }^{44}$ Outlining the mandate of delegates to the Conference, he declared:

You have the mandate to deliberate upon the structure of the Nigerian nationstate and to work the modalities for ensuring good governance; to devise for our people a system of government guarantying equal opportunity, the right to aspire to any public office, irrespective of state of origin, ethnicity or creed and thus engender a sense of belonging in all citizens. ${ }^{45}$

Although the Constitutional Conference of 1994/95 was not bedeviled by serious acrimonious debate over the Sharia, the 1998 Constitutional Debate Co-ordination Committee recommendation for the retention of the provisions of the 1995 draft Constitution became smeared in severe controversy. The South West media outfits under some religious influences discredited the then Head of State, General Sani Abacha, by spreading false rumor that there was

\footnotetext{
43Yadudu, 51.

44Federal Government, Report of the Constitutional Conference Containing the Draft Constitution, 1st ed. (Lagos: Federal Government Press, 1995), 12.

${ }^{45}$ Federal Government.
} 
disagreement at the highest decision making body of the ruling military brass over what should be the position of the Sharia in the constitution. ${ }^{46}$

The Holy Qur'an which is the first source of rules in Islam only provides some fundamental principles pertaining to the political affairs of Muslims. The Islamic law (Sharia) indeed refrains from providing detailed regulations for all changing requirements of our social existence. The need for continues temporal legislation is therefore, self-evident. In a Muslim State, the legislation would relate to many problems of administration not touched upon by the Sharia. It is up to the community to evolve the relevant detailed legislation through an exercise of independent reasoning (Ijtihad) in consonance with the spirit of the Sharia in the best interests of the nation. In matters affecting the communal side of our life no legislative reasoning or decision can be left to the discretion of individuals, but they must be based on a definite consensus (ijma') of the whole community. ${ }^{47}$

Chief among such flexible aspects of Islam is its constitution i.e. Quran. Although the constitutional rights and obligations of the rulers and the ruled are firmly established, the organization of the government and the procedures for leadership election in the political process are left open. The Muslim communities at any point in time are obliged to evolve from this constitutional framework of the institutions which meet the needs of their era.48 Thus, it has to be admitted, that the Qur'an, being a book of religious guidance, is not an easy reference for legal studies. It is more particularly and appeals to faith and the human soul rather than a classification of legal prescriptions. Such prescriptions are comparatively limited and few. 49

Although the Constitutional Conference of 1994/95 was not bedeviled by serious acrimonious debate over the Sharia, the 1998 Constitutional Debate Co-ordination Committee recommendation for the retention of the provisions of the 1995 draft Constitution became smeared in severe controversy. The

\footnotetext{
${ }^{46}$ Auwalu Hamisu Yadudu, “Dialogue of the Deaf: The Shari'ah Debate in Nigeria," in A Digest of Islamic Law and Jurisprudence in Nigeria. A Publication of National Association of Muslim Law Students (NAMLAS), ed. Zakariyau Husseini (Auchi: Darun-Nur, 2003), 1-5.

47Thaib, "Concept of Political Authority in the Islamic Political Thought," 12.

48Thaib.

49'Abd al-Wahhāb Khalāf, 'Ilm al-Fiqh (Cairo: Matba'atal-Nasr, 1957), 34-5.
} 
South West media outfits under some religious influences discredited the then Head of State, General Sani Abacha, by spreading false rumor that there was disagreement at the highest decision making body of the ruling military brass over what should be the position of the Sharia in the constitution. ${ }^{50}$

\section{Sharia and the 1999 Constitution}

The introduction of Islamic Penal Codes is one of the many controversies confronting Nigerian democracy. Since its inception, adoption of full Sharia law has been criticized as unconstitutional. The political stage has witnessed varying passionate arguments for and against its continued existence in a multi-cultural and diverse nation like Nigeria. The inability of the government to tactfully resolve the issue has led to many violent clashes between adherents of rival religions. Thousands of lives have been lost as a result, and huge amount of property have been destroyed. Against this backdrop, many have continued to ask the questions. Is there any legal or constitutional foundation for the enactment of Sharia law in Nigeria? ${ }^{51}$ However, to some extent, the enactment of Sharia law in Nigeria is a prime example of the relative success of Nigeria's multi-state federalism in regards to governing diversity, i.e., managing subnational identities and interests, is the constitutional recognition of the rights of states to establish customary courts. Of particular note here is the political autonomy to establish a Sharia Court of Appeal with civil jurisdiction on questions of Islamic personal law. This has enabled Nigeria's Muslimdominated northern states to give public recognition to the Islamic religious heritage of their constituents without derogating from the cultural integrity and autonomy of non-Muslim states, or violating the basic secularity or religious neutrality of the federal government. Perhaps, the critical test to this constitutional accommodation of Sharia Law coincided with Nigeria's transition from Northern dominated military rule to a Southern-led civilian regime in 1999. This transition revived fierce debates on what the status of Sharia should be in an independent, secular state. The issue attained even higher importance when Zamfara became the first state to extend Sharia from

\footnotetext{
50Badamasiuy and Okene, "Shariah Implementation in a Democratic Nigeria: Historical Background and the Quest for Developmental Legality," 147.

${ }^{51}$ Ikenga K. E. Oraegbunam, "Islamic Criminal Law and Constitutionalism in Nigeria: Any Lessons from Turkey?", Journal of Law, Policy and Globalization 33 (2015): 25-45, https://www.iiste.org/Journals/index.php/JLPG/article/view/19335.
} 
personal status issues into the domain of criminal justice and to establish Sharia courts with corresponding criminal jurisdiction. After Zamfara showed the way, 11 other Northern states soon followed with similar legislative programs..$^{52}$ Ahmed Sani of Zamfara leading other states' governors explored the various provisions of the enabling 1999 Nigerian Constitution to introduce the Sharia in his state. Apparently the Governor had made the introduction of the Islamic criminal law as part of his campaign manifesto. ${ }^{53} \mathrm{He}$ relied on the provisions of sections 4(7), 6(4) \& (5), 38, 277-278 as relevant schedules. Section 38(1) of the 1999 constitution of the Federal Republic of Nigeria, for instance, states that "Every person shall be entitled to freedom of thought, conscience and religion, including freedom to change his religious belief, and freedom (either alone or in community with others, and in public or private) to manifest and propagate his religion or belief in worship, teaching, practice and observation." The Governor approved the bill establishing the Sharia penal code passed by the Zamfara House of Assembly in January 2000, emphasizing the fact that his State has not contravened the constitutional provision forbidding state religion. Sani and Muslim scholars insisted that if Zamfara State were to adopt Islam as a State religion, there would not have been magistrate courts or high courts and even churches in the State. What the State did was to have two legal systems; Sharia Courts to administer Sharia Laws for Muslims and Conventional Courts (Magistrate and High Courts) to Administer Common Law for non-Muslims. ${ }^{54}$

To the bulk of suspecting non-Muslims in the country, especially Christians, the introduction of the criminal aspect of Islamic Law by Zamfara and indeed any State in Nigeria was provocative. According to them, doing this would mean having two constitutions in a common geo-polity. Ben Nwabueze a former Nigerian Minister of Justice used the instrumentality of the Constitution to oppose the adoption of the Sharia legal system. Nwabueze insists that the practice of the Sharia and the observance of the moral precepts and injunctions in the Qur'an are a personal matter for the individuals to be inculcated by

\footnotetext{
52Daniel E. Agbiboa, "Federalism and Group-Based Inequalities in Nigeria" (Global Centre for Pluralism Accounting for Change in Diverse Societies, University of Pennsylvania, 2017), 13.

53Badamasiuy and Okene, "Shari'ah Implementation in a Democratic Nigeria: Historical Background and the Quest for Developmental Legality," 148.

${ }^{54}$ Yadudu, "Dialogue of the Deaf: The Shari'ah Debate in Nigeria," 3-4.
} 
teaching and preaching in the Quranic Schools and Mosques, by individual selfabnegation and self-discipline, not by enforcement through the coercive machinery of government belonging to Muslims and non-Muslims alike. Giving legal and intellectual backing to the anti-Sharia position, Nwabueze writes that the Sharia Law adopted by Zamfara State is inconsistent with some provisions in the fundamental rights Chapter (chapter IV) of the 1999 constitution. He observes that the Sharia law of the Sharia states does not satisfy section 33(12), which provides that a person shall not be convicted of a criminal offence unless that offence is defined and the penalty prescribed in the written Law in form of an act of the National Assembly or Law of a state, any subsidiary legislation or instrument under the provision of a law. 55

To the protagonists of the Sharia legal system in Nigeria, Nwabueze's treatise argued only the usual intellectual stereotype of the anti-Sharia sentiments. To them, the treatise failed to explore and juxtapose the various constitutional clauses and provisions to see the historic-psychology of Muslims and their legal system, which predated the existence of Nigeria as a nation state. Islam to the pro-Sharia is a comprehensive civilization and worldview, which is both metahistorical and international. It transcends time and space and embraces all kinds of peoples, languages and culture in the world. ${ }^{56}$

Accordingly, since the Nigerian federation is predicated on the principles of democracy and social justice, which uphold the equality of rights, obligations and opportunities before the law, it presupposes that such principles prohibit discrimination on the same grounds, which inter alia include religion. As such, to disallow Muslims from implementation of their religious requirements is against the intent of democracy in Nigeria, since the 1999 Constitution demands from the Government at whatever level to exercise such power that will achieve public order, safety, peace and accountable government. The provision of all these and more is the basic objective of the Sharia, which has become a written and codified law for over a thousand and four hundred years. $^{57}$

\footnotetext{
55Ben Nwabueze, "Freedom of Religion: The Religious Neutrality of the State under the Constitution and the Sharia Controversy," Bulletin of Ecumenical Theology 13 (2001), 91-121.

56Badamasiuy and Okene, "Shari'ah Implementation in a Democratic Nigeria: Historical Background and the Quest for Developmental Legality," 149.

${ }^{57}$ Badamasiuy and Okene.
} 
Hon. Justice Mohammad Bello argues that when the present clamor for the Sharia began, some people rushed to the opinion that a state government lacks the constitutional power to enact Sharia in its territory he stated: However, a brief examination of the 1999 constitution reveals that section 4 of the Constitution has divided the legislative powers of Government between the Federation and the State. In its second schedule, it specifies the exclusive legislative list, on which only the Federation may make laws, and also the concurrent legislative list, on which both the Federation and the States may make laws. In addition, it empowers the States to make laws on any other matter not included in the two lists; Sharia falls within the residue and consequently, a State has the constitutional power to make law relating to Sharia. ${ }^{58}$

Furthermore, section 6 of the Constitution empowers with respect to which the House of Assembly of a State may make laws. It is axiomatic, therefore, that a State may establish a Sharia Court of first instance. Section 275 specifically empowers any State that requires it to establish its Sharia Court of Appeal to hear appeal from its lower courts. ${ }^{59}$ The Constitution does not stop here. It proceeds to adopt all laws and the courts which existed before 29 May, 1999 when the Constitution came into force as deemed to have been made or established by the State House of Assemblies. Accordingly, the Sharia Civil law, the Pena Code and the Area Courts law have been adopted by Section 315 and 316 of the Constitution. Finally, on the civil aspect of the Sharia, it may note that there is no limitation or restriction on the application, observance and enforcement of the Sharia in the Constitution. ${ }^{60}$

Interestingly, the Federal Government after unsuccessful moves to prevent other Muslim Governors, especially of the Northern States, from applying Islamic Laws, attempted to use blackmail and federal might to quash the desire. For instance, the Nigeria Air Force in Kaduna prevented Muslim crowd from traveling to Kano during the state launching of the Sharia on the 21st of June 2000. Eventually, the Sharia case was referred to the Federal Ministry of

\footnotetext{
58Muhammad Bello, "Shari'ah in the Lights of Nigerian Constitution," in Perspectives in Islamic Law and Jurisprudence (A Publication of National Association of Muslim Law Students - NAMLAS), ed. M. Oloyede Adbul-Rahman (Ibadan: NAMLAS, 2001), 63-71.

${ }^{59}$ Bello, 69.

${ }^{60}$ Bello.
} 
Justice under Chief Kanu Agabi, a Christian and legal luminary, which ruled in favor of the legality of the Law in Muslim dominated states and on Muslims alone. It is worthy to mention here that apart from Governor Ahmed Sani of Zamfara, all other Governors of the Sharia States introduced the legal system as a result of the pressure by the electorates. Again, the 2003 political campaigns were anchored on the promise by various contestants at various political units and levels in the Muslim dominated areas, especially in northern Nigeria that they shall implement the Sharia Law. It is instructive to note that Mr. Ibrahim Shekarau won election in 2003 and 2007 as Governor of Kano State largely on this platform. ${ }^{61}$ Yet, for all its criticisms, the extension of Sharia Law in northern Nigeria may actually "exemplify the efficacy of Nigerian federalism in responding innovatively, constitutionally and democratically to popular pressures for ethno-religious self-rule in the northern Muslim states." ${ }^{\prime 2}$ Sharia advocacy by elected officials serves as an informational shortcut for Muslim citizens, who interpret a commitment to Sharia-inspired policies as a commitment to supporting social, economic, and political reforms meant to provide economic and physical security and accountability. ${ }^{63}$

\section{Conclusion}

The larger part of Nigeria areas experienced the full application of Shari'ah before the advent of the British colonial rule. The British meticulously eroded the application of the law in over six decades of administration in Nigeria. The return of democracy to political governance in 1999 rekindled the fervor and agitation for the Islamic legal system using the framework of the operational 1999 constitution. Though, the application of the law so far in most of Northern Nigeria is discriminatively applied while the good governance side of the system is not felt by the people. However, Muslims have an onerous responsibility in this matter. If Muslims take a wider view of Sharia it would go

\footnotetext{
${ }^{61}$ Badamasiuy and Okene, "Shari'ah Implementation in a Democratic Nigeria," 149.

${ }^{62 R}$. T. Suberu, Ethnic Minority Conflicts and Governance in Nigeria (Ibadan: Spectrum Books Limited, 1997), 73.

${ }^{63}$ Thomas B. Pepinsky, R. William Liddle, and Saiful Mujani, “Testing Islam's Political Advantage: Evidence from Indonesia," American Journal of Political Science 56, no. 3 (2012): 584-600, https://doi.org/10.1111/j.1540-5907.2011.00570.x.
} 
a long way in removing it from the realm of politics and constitutional debate. Muslims do not require constitutional endorsement to do so many things which are the Shari'ah demand of all Muslims. Muslim could and should emulate the Sharia model in regulating their family life without resorting to the courts.

Muslims have the constitutional freedom to tailor their educational system to conform to the Islamic ideals. Muslims could and should implement the Zakat social security to address the socio-economic problems of the times. In market-place, at home and in the wider community, they could and should apply Islamic rules of social relations to evolve a dynamic community. Muslims could do so many things commanded by the Sharia without submitting to the censorship or the manipulation of politicians. For all these things, Muslims do not need more constitutional backing. If the Muslims heed this, it would go a long way in putting the politicians out of business and hopefully, live in peace with their Christians neighbors. The paper therefore suggests that matters relating specifically to religions should be removed from the deliberative process of drafting constitutions in the country. If this is done the politicians would have no object of passionate appeal or manipulation.[a]

\section{BIBLIOGRAPHY}

Abun-Nasr, Jamil M. "The Recognition of Islamic Law in Nigeria as Customary Law." In Law, Society, and National Identity in Africa, edited by Jamil M. Abun-Nasr, Ulrich Spellenberg, and Ulrike Wanitzek. Hamburg: H. Buske, 1990.

Agbiboa, Daniel E. "Federalism and Group-Based Inequalities in Nigeria." Global Centre for Pluralism Accounting for Change in Diverse Societies, University of Pennsylvania, 2017.

Ali, Yusuf. "The Legal Status and Politics of Shariah in Nigeria." Yusuf Ali \& Co., n.d. https://yusufali.net/articles/The_Legal_Status_and_Politics_of_ Shariah_in_Nigeria.pdf.

Anderson, J. N. D. Islamic Law in Africa. London: Frank Cass, 1955.

Aniagolu, Anthony Nnaemezie. The Making of the 1989 Constitution of Nigeria. Ibadan: Spectrum Books Limited, 1993. 
Badamasiuy, Juwayriya, and Ahmed Adam Okene. "Shari'ah Implementation in a Democratic Nigeria: Historical Background and the Quest for Developmental Legality." Journal of Politics and Law 4, no. 2 (2011): 144-52. https://www.academia.edu/890544/Shariah_Implementation _in_Democratic_Nigeria_Historical_Background_and_The_Quest_for_Dev elopmental_Legality.

Bello, Muhammad. "Shari'ah in the Lights of Nigerian Constitution." In Perspectives in Islamic Law and Jurisprudence (A Publication of National Association of Muslim Law Students - NAMLAS), edited by M. Oloyede Adbul-Rahman, 63-71. Ibadan: NAMLAS, 2001.

Federal Government. Report of the Constitutional Conference Containing the Draft Constitution. 1st ed. Lagos: Federal Government Press, 1995.

Gbadamasi, G. O. "The Growth of Islam Among the Yorubas (1841-1908)." University of Ibadan, 1968.

"Gongola State of Nigeria Executive Council." en.wikipedia.org, n.d. https://en.wikipedia.org/wiki/Gongola_State.

Harbold, Dell Gillette \&, and William Henry Hitchner. Modern Government: A Survey of Political Science. New York: Dodd, Mead \& Company, 1966.

Igbuzor, Otive. "Nigeria's Experience in Managing the Challenges of Ethnic and Religious Diversity through Constitutional Provisions," n.d. http://www.idea.int/asia_pacific/myanmar/up/oad/burma_report .

Jones, Lindsay, ed. "History of Shariah." Encyclopedia of Religion. USA: Macmillan Reference, 2004.

Karibi-Whyte, A. G. History and Sources of Nigerian Criminal Law. Ibadan: Spectrum Books Limited, 1993.

Khalāf, 'Abd al-Wahhāb. 'Ilm Al-Fiqh. Cairo: Matba'at al-Nasr, 1957.

Nwabueze, Ben. "Freedom of Religion: The Religious Neutrality of the State under the Constitution and the Sharia Controversy." Bulletin of Ecumenical Theology 13 (2001).

Nwabueze, Ben O. Ideas and Facts in Constitution Making. Ibadan: Spectrum Books Limited, 1993.

Okunola, Muri. "The Relevance of Sharia to Nigeria." In Islamic Law in Nigeria (Application \& Teaching), edited by Syed Khalid Rashid. Lagos: Islamic Publications Bureau, 1986.

Oloyede, Is-haq Olanrewaju. "Theologising the Mundane, Politicising the Divine: The Cross-Currents of Law, Religion and Ppolitics in Nigeria." 
African Human Right Law Journal 14, no. 1 (2014): 178-202. http://www.ahrlj.up.ac.za/issues/2014/volume-14-no-1-2014/41issues/volume-14-no-1-2014/435-theologising-the-mundanepoliticising-the-divine-the-cross-currents-of-law-religion-and-politicsin-nigeria.

Omoruyi, Omo. "An Appeal to President Olusegun Obasanjo: Nigeria: Neither an Islamic nor a Christian Country." Nigeriaworld, 2001. https://nigeriaworld.com/feature/publication/omoruyi/0307001.html

Oraegbunam, Ikenga K. E. "Islamic Criminal Law and Constitutionalism in Nigeria: Any Lessons from Turkey?" Journal of Law, Policy and Globalization 33 (2015): 25-45. https://www.iiste.org/Journals/ index.php/JLPG/article/view/19335.

Pepinsky, Thomas B., R. William Liddle, and Saiful Mujani. "Testing Islam's Political Advantage: Evidence from Indonesia." American Journal of Political Science 56, no. 3 (2012): 584-600. https://doi.org/ 10.1111/j.1540-5907.2011.00570.x.

Rashid, S. Khalid. "Introduction." In Islamic Law in Nigeria (Application \& Teaching), edited by Syed khalid Rashid. Lagos: Islamic Publications Bureau, 1986.

Suberu, R. T. Ethnic Minority Conflicts and Governance in Nigeria. Ibadan: Spectrum Books Limited, 1997.

Sulaiman, Ibrahim R. "The Shari'ah and the Constitution." In Islamic Law in Nigeria (Application \& Teaching), edited by Syed Khalid Rashid. Lagos: Islamic Publications Bureau, 1986.

Thaib, Lukman. "Concept of Political Authority in the Islamic Political Thought." International Journal of Humanities and Social Science Invention 1, no. 1 (2012): 12-19. www.ijhssi.org.

Yadudu, Auwalu Hamisu. "Dialogue of the Deaf: The Shari'ah Debate in Nigeria." In A Digest of Islamic Law and Jurisprudence in Nigeria. A Publication of National Association of Muslim Law Students (NAMLAS), edited by Zakariyau Husseini. Auchi: Darun- Nur, 2003.

Yadudu, Auwalu Hamisu. "The Prospect for Shari'a in Nigeria." In Islam in Nigeria, edited by Nura Alkali, 36-58. Ibadan: Spectrum Books Limited, 1993. 
